\title{
Cutaneous Larva Migrans - Report of 2 new Cases Locally Acquired in Serbia
}

\author{
Jelena PERIĆ1, Branislav LEKIĆ1, Vesna RELJIĆ1, Lana ĆIRKOVIĆ ${ }^{1}$, Dušan ŠKILJEVIĆ1,2 \\ ${ }^{1}$ Clinic of Dermatovenereology, Clinical Center of Serbia, Belgrade, Republic of Serbia \\ 2University of Belgrade, School of Medicine, Belgrade, Republic of Serbia \\ *Correspondence: Doc. Dr. Dušan Škiljević, Department of Dermatovenereology, School of Medicine, \\ University of Belgrade, Pasterova 2, 11000 Belgrade, Serbia, E-mail: dusanskiljevic@yahoo.com
}

UDC 616.5:616.995.132

\begin{abstract}
Cutaneous larva migrans (CLM) is a parasitic skin disease caused by the accidental percutaneous penetration and subsequent intraepidermal migration of larvae of various nematode parasites of the hookworm family. The hookworms responsible for CLM are spread worldwide, but the infection occurs mostly in tropical and subtropical climates. Nowadays, because of ever increasing foreign travel, the disease is no longer confined to these areas. Moreover, a significant increase of autochthonous cases in southern Europe has been observed in recent years. We report two new patients from Serbia who acquired CLM, none of them having traveled abroad. As the recommendations for the treatment of CLM are not uniform, two different treatment modalities were applied in these patients, both with an excellent response.
\end{abstract}

Key words: Larva Migrans; Skin Diseases, Parasitic; Hookworm Infections; Treatment Outcome; Case Reports; Albendazole; Ivermectin

\section{Introduction}

Cutaneous larva migrans (CLM) is a zoonotic infestation of the skin caused by the larvae of various animal nematode parasites of the hookworm family. The most common causes of CLM are: Ancylostoma braziliense, Ancylostoma caninum and Uncinaria stenocephala, but other species have also been reported $(1,2)$.

In Europe, CLM is usually seen among the travelers returning from subtropical or tropical countries who have visited beaches there. Lesions are typically distributed on the feet, thighs and buttocks, but any part of the body, which has been in the direct contact with the contaminated soil and sand, could be affected (3). Clinically, CLM is characterized by the presence of intensely pruritic, erythematous, serpinginous tracts that keep advancing up to several centimeters a day. The tunnels left behind the migrating parasite desiccate and become dry and crusted (3). Palmar and plantar lesions frequently contain some serous fluid, although vesicular and bullous lesions might also develop everywhere on the skin in $9-15 \%$ of cases (4).
Except pruritus, which could be severe and lead to epidermal damage and secondary infections due to the rubbing and scratching, CLM is a benign, self-limiting disease. It is rarely accompanied by peripheral blood eosinophilia, and usually not associated with systemic symptoms $(3,5)$.

The diagnosis of CLM is clinical, based on the characteristic skin lesions in a patient who has traveled to high-risk areas (4). Biopsy is sometimes performed, but it is not necessary for the diagnosis as the parasite is located 1-2 cm ahead of the leading edge of a tract and could be easily missed (6). Dermoscopy has become a useful, additional diagnostic tool in recent years (7).

The prognosis of CLM is generally favourable, even without treatment. In most cases, the larva dies and the lesions resolve spontaneously within 2-8 weeks. Sometimes untreated disease lasts longer and may persist up to 2 years. With specific therapy, remission is usually observed within a week $(8,9)$.

Herein, we describe two new autochthonous cases of CLM in Serbia which were 
successfully treated with different treatment modalities.

\section{Case Reports}

Case 1. A 72-year-old man, from a city in western Serbia, was admitted to our Department in August 2016 because of intensively pruritic, migrating and linear erythema in the presternal area. The skin changes appeared 5 months before admission and they were treated with oral antihistamines and different topical antibiotics, without effect. The patient was otherwise healthy and denied recent travel to endemic regions. However, he reported that his favorite hobby was fishing at the local river, where he might have got in contact with a larva.

On examination, erythematous, serpiginous and raised tract was present over the patient's presternal region (Figure 1). Over the next few days, the lesion progressed toward the upper left side of the thorax. Regional lymphaedenopathy was not present, and there were no other significant findings and systemic symptoms. The routine blood parameters, including complete blood count and total serum IgE, were within normal limits. The diagnosis was made based on the typical clinical picture and the history of contact with potentially contaminated sand around the river.

The patient's response to oral albendazole, given at a dose of $400 \mathrm{mg}$ daily for three days, was excellent. Pruritus improved rapidly in the next few days and the skin lesions resolved completely within 10 days. No side effect was observed during the treatment period. On the follow-up visit after one month, only hypopigmentation at the affected site was present (Figure 2).

Case 2. A 31-year-old man, from a small town in central Serbia, was admitted to our Department in the middle of September 2016 because of intensively pruritic, vesiculobullous and linear lesion on the right hand. The skin changes appeared 15 days before admission and were treated with topical corticosteroids without improvement. Otherwise, the patient was healthy and did not report any other associated symptoms, neither did he travel to endemic regions. However, because of his job, he had to spend a lot of time during that summer in a warm and moist environment (forest), where he may have been exposed to a parasite.

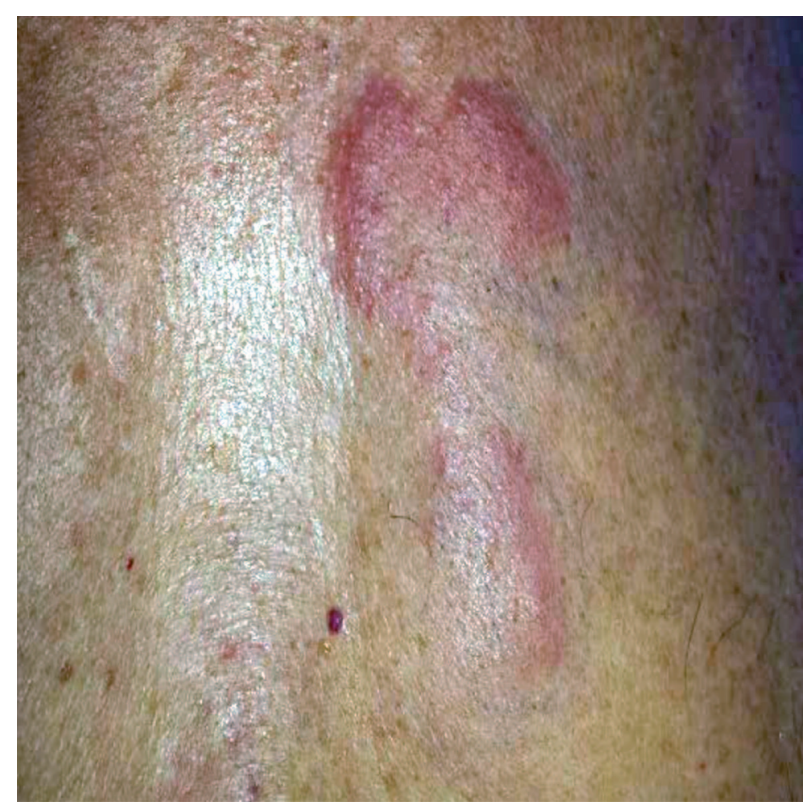

Figure 1. Erythematous, serpiginous, raised

On examination, a raised, erythematous, serpiginous tract, with bullae formation was observed on the patient's right hand (Figure 3). Over the next few days, the lesion advanced progressively. Regional lymphadenopathy was not present, and there were no other significant findings and systemic symptoms. The routine blood tests were within normal ranges. Peripheral blood eosinophilia and total serum IgE elevation were not present. The diagnosis was made based on the skin lesions typical for CLM and the history of contact with possibly contaminated soil in the warm and moist forest.

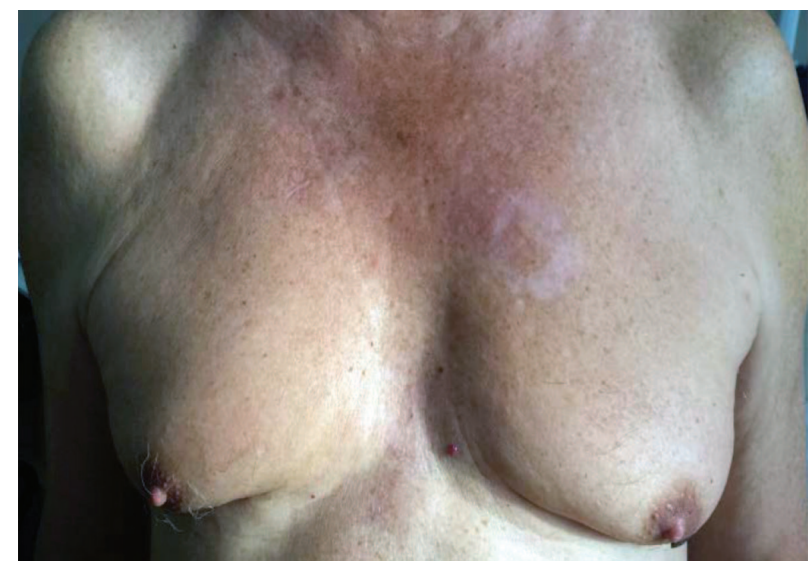

Figure 2. Residual hypopygmentation after tract over the presternal region treatment 


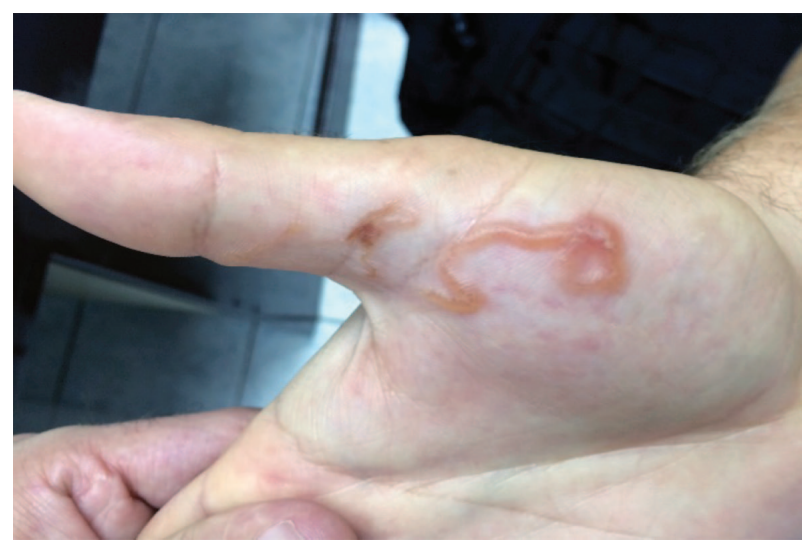

Figure 3. Serpiginous, bullous tract on the right hand

The patient was treated with oral ivermectin, given as a single dose of $200 \mu \mathrm{g} / \mathrm{kg} / \mathrm{kg}$ and his response was excellent. The pruritus disappeared almost immediately after the treatment and the lesions resolved completely within the next 15 days (Figure 4). No side effect was observed during the treatment period.

\section{Discussion}

CLM is a parasitic dermatosis most commonly found in tropical and subtropical areas like the Caribbean, South and Central America, Southern-East Asia and Africa $(3,5)$. The parasites live in the small intestines of dogs, cats and wild animals, from where they release their eggs in the feces. Under favorable environmental conditions of temperature and humidity, these eggs hatch and mature into infectious larval form (filariform larvae) in the sand or soil. At this stage, larvae are able to

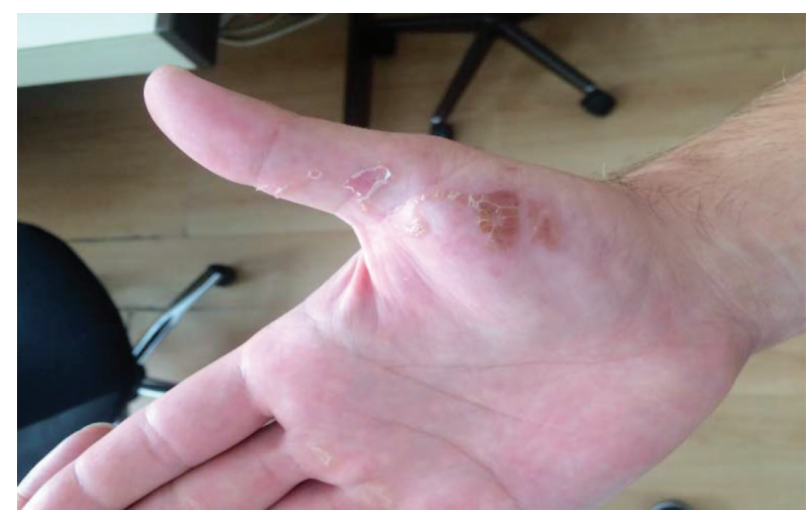

Figure 4. Almost complete resolution of the lesions 15 days after the treatment penetrate the intact skin by using their proteases and to infect a new host $(1,10)$. Once inside the mammalian body, filariform larvae start migrating after an incubation period of about a week (11). Depending on the new host, the parasite migration might eventuate in two different ways. Within the body of their natural hosts, filariform larvae penetrate the basement membrane, invade the dermis, and then travel through the bloodstream or lymphatic system to the lungs, ascend into the trachea to be coughed and swallowed. In the intestine of these animals the larvae molt into adult, sexually mature worms (5). The humans could also be affected, but due to the deficiency of collagenase the parasites are not able to penetrate the basement membrane, invade deeper structures and complete their life cycle in the human skin. Therefore, in the human body, the larvae remain trapped in the outer layers of the skin, they migrate aimlessly a few millimeters to a few centimeters per day, produce the lesions typical for CLM without associated systemic symptoms, until they eventually die $(3,6)$.

The endemic nature of this disease could be explained by the impact of poor sanitary conditions associated with humid and hot climate $(5,12)$. The infestation is typically acquired through direct contact with sand or soil contaminated with filariform larvae derived from infected animal feces. Frequently, there is the history of walking barefoot or sitting and lying on the wet, sandy beaches, since the warm and humid environment enables nematode larvae to survive and be infective for several weeks or even several months $(3,12)$.

Until now, CLM has been a rare disease in Europe, usually diagnosed in the tourists arriving from endemic regions, with only sporadic reports of infestations locally developed. In the recent years, the diagnosis of CLM in Europe has become more frequent, probably because of much more frequent foreign travel. Furthermore, the striking rise in numbers of locally acquired cases was noticed, most commonly in southern European countries $(10,11,13,14)$. It is likely that global warming and climate changes with an increase in ambient temperature and humidity, which favor the larva development, are responsible for this phenomenon $(10,11)$. 
Although CLM is a self-limited disease that usually resolves spontaneously within 2-8 weeks, the treatment is advisable because of intense pruritus and high risk for infection (12). Oral ivermectin, given as a single dose of $200 \mu \mathrm{g} / \mathrm{kg}$, oral albendazole, given at a dose of $400 \mathrm{mg}$ daily for three days, topical ivermectin, or topical thiabendazol are most frequently used drugs $(10,15)$. A single dose of oral ivermectin is usually considered to be a drug of choice, but the recommendations for the management of cutaneous larva migrans are not uniform, and the recommended methods are not always available neither they are always effective $(10,15)$.

In conclusion, our personal experience confirms an increase in the incidence of autochthonous cases of CLM in Europe since only 2 cases of infestations locally developed were reported in this country before (1). In addition, based on our results and a literature review, we can make the conclusion that ivermectin given as a single dose of $200 \mu \mathrm{g} / \mathrm{kg} /$ $\mathrm{kg}$, as well as albendazole given at a dose of $400 \mathrm{mg} /$ day for three days are effective and reliable treatment for this condition.

\section{Abbreviations}

CLM - cutaneous larva migrans

\section{References}

1. Tomovic M, Skiljevic D, Zivanovic D, Tanasilovic S, Vesic S, Djakovic Z, et al. Two cases of probable endogenous extensive cutaneous larva migrans in Serbia. Acta Dermatovenerol Alp Pannonica Adriat. 2008;17(1):37-40.

2. Meotti CD, Plates G, Nogueira LL, Silva RA, Paolini KS, Nunes EM, et al. uㅡ므르ou the scalp: atypical presentation of a common disease. An Bras Dermatol. 2014;89(2):332-3.
3. Tekely E, Szostakiewicz B, Wawrzycki B, KądzielaWypyska G, Juszkiewicz-Borowiec M, Pietrzak A, et al. Cutaneous larva migrans syndrome: a case report. Postepy Dermatol Alergol. 2013;30(2):119-21.

4. Heukelbach J, Feldmeier $\mathrm{H}$. Eppidemiological and clinical characteristics of hookworm-related cutaneous larva migrans. Lancet Infect Dis. 2008;8(5):302-9.

5. Miljković J, Breznik V. Cutaneous larva migrans in two Slovenian travelers returning from Brazil. Acta Dermatovenerol Alp Pannonica Adriat. 2008;17(2):83-5.

6. Nurjahan MI, Tevaraj P. Rash in a foreign worker. Malays Fam Physician. 2016;11(2-3):39-41.

7. Aljasser MI, Lui H, Zeng H, Zhou Y. Dermoscopy and near-infrared fluorescence imaging of cutaneous larva migrans. Photodermatol Photoimmunol Photomed. 2013;29(6):337-8.

8. Veraldi S, Bottini S, Persico MC, La Vela V. Larva migrans cutanea. Rome: Mediprint; 2010. p. 39-41.

9. Veraldi S, Persico MC, Francia C, Schianchi R.

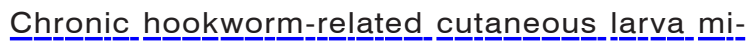
grans. Int J Infect Dis. 2013;17(4):e277-9.

10. Panés-Rodríguez A, Piera-Tuneu L, López-Pestaña $A$, Ormaetxea-Pérez N, Gutiérrez-Támara P, IbarbiaOruezabal S, et al. Autochthonous cutaneous larva migrans infection in Guipúzcoa. Actas Dermosifiliogr. 2016;107(5):407-13.

11. Gutiérrez García-Rodrigo C, Tous Romero F, Zarco Olivo C. ㅁutanewarmer É 2017;31(1):e33-5.

12. Vano-Galvan S, Gil-Mosquera M, Truchuelo M, Jaén P. Cutaneous larva migrans: a case report. Cases J. 2009;2(1):112.

13. Tamminga N, Bierman WF, de Vries PJ. uㅡ므ㅁㅡㅡㅡㅡㄴ larva migrans acquired in Brittany, France. Emerg Infect Dis. 2009;15(11):1856-8.

14. Akkouche W, Ahmed SA, Sattin A, Piaserico S, Calistri A, De Canale E, et al. Autochthonous hookwormrelated cutaneous larva migrans disease in Northeastern Italy: a case report. J Parasitol. 2015;101(4):488-9.

15. Wolf P, Ochsendorf FR, Milbradt R. Current therapeutic possibilities in cutaneous larva migrans. Hautarzt. 1993;44(7):462-5.

\section{Kutana larva migrans - prikaz dva nova slučaja infestacije nastale u Srbiji}

\section{Sažetak}

Kutana larva migrans je parazitarna dermatoza uzrokovana akcidentalnom perkutanom penetracijom i daljom intraepidermalnom migracijom larvi različitih nematodnih parazita iz familije rudarskih glista. Larve parazita odgovorne za nastanak bolesti rasprostranjene su u čitavom svetu, ali se infekcija najčešće registruje u tropskim i suptropskim regionima. Zbog sve većeg broja putovanja $u$ inostranstvo, bolest u savremenom svetu 
više nije ograničena na ova područja. Pored toga, poslednjih godina zabeležen je i porast broja autohtonih slučajeva u južnim delovima Evrope. Prikazujemo dva nova pacijenta iz Srbije kod kojih je postavljena dijagnoza kutana larva migrans, a kod kojih nisu postojali anamnestički podaci o prethodnim putovanjima u inostranstvo. S obzirom da preporuke za lečenje ove bolesti nisu uniforme, kod pacijenata su primenjena dva različita terapijska modaliteta, oba sa odličnim terapijskim odgovorom.

Ključne reči: Larva migrans; Kožne parazitske bolesti; Infekcije rudarskom glistom; Ishod terapije; Prikazi slučajeva; Abendazol; Ivermektin 